\title{
SOME OF THE FACTORS FOSTERING POSITIVE THINKING
}

\author{
ABDULLAYEVA Shafahat ${ }^{1 *}$ \\ ${ }^{1}$ Academy of the Public Administration under the President ( AZERBAIJAN) \\ E-mail:anfas.07@mail.ru
}

\begin{abstract}
This article aims to dive into some of the factors fostering positive thinking in youth. In this framework, a survey was conducted with the voluntary participation of 332 university students and the results were tested through discriminant, correlation and ROC analysis. The statistics based on the survey responses had revealed that formation of positive mindset were favourably influenced by family, happy childhood, friendship, love, optimistic outlook, self-confidence and faith in God, while money, age and gender were evaluated as non impacting components in this regard. Certain suggestions were put forward based on the results yielded.
\end{abstract}

Key words: positive psychology, happiness, positive feelings, positive thinking, fostering factors

JEL: D10

DOI: 10.5937/intrev2103148A

UDC: 159.942 .53

COBISS.SR-ID 55162889 


\section{INTRODUCTION}

Positive psychology was evolved as opposite to negative psychology - it focuses on studying qualities shaping human being, maintaining positivity and becoming stronger in lieu of psychological disorders. Although the study of positive qualities has long been controversial, it has always maintained its relevance, as every generation constantly chase happiness. There exist studies presenting the desire for happiness as an immanent quality, and the pursuit of happiness is the ultimate goal of human existence [1][2][3][4][5].

As a result of the studies on the subject, the theory of positive psychology was developed. Happy people at first sight may occur having plenty of positive emotions only with no room for negativity in their lives. This would not be a correct approach. Kahnemann and Tversky [6] proved experimentally that happiness is not about a subtraction of negative moments from the positives, reinforcing what White and his colleagues' (at all) [7][8] studies had revealed. Practicing the power of positive thinking helps to come out of the negativity [8][9].

People with positive thinking do better on all fronts, from career to family and creativity and they tend to live happier life [10][11][12][13][14][15][16]. This had been proved with experimental studies [17][18][19][20][21][22].

Experiments had shown that those with positive mental attitude have seen their intellectual capability improved. Studying the role of positivity in the human development, Fredrickson [10][23] had managed to show that positivity not only yields positive outcomes for human development and behavior but also builds, shapes and broadens physical, intellectual and social capabilities [24][25][26][27][28][29]. These experiments suggest that tuning in to positive thoughts develops a specific mindset [30][31][32][33]. While negative thinking activates criticism [34][35][36], positive thinking, in its turn, boosts creativity, improves tolerance for challenges, and capability to not only see the negatives but also appreciate the good in situations (Aspinw) [34][35][36][37][38]. Positive thoughts hence are a basic, necessary quality for a person to lift his happiness [39][40][41][42][43][44][45].

What factors influence one's positive thinking? It is worth noting that, the number of psychologists have proven the optimism as one of the personality traits that had been inherited [46][47][48][49], however the studies conducted focus on optimism developed across the life span, not the one inherited. This article looks into some of the factors fostering positive thinking [50][51][52][53][54][55].

With demographic factors in mind, we first suggested that gender and age do not present a positive effect on shaping positive thinking. Hypothesis 1a: Gender does not impact positive thinking. Hypothesis $1 \mathrm{~b}$ : Age does not affect positive thinking.

A survey of 35,000 people has found out that while family conflict causes negative effect on individual's mood, it also presents great advantages [56][57]. Although, single and divorced individuals have higher average levels of life satisfaction than the ones with failed marriage, those who have positive qualities in the family are able to avoid, resolve conflicts and build harmonious relationships. It had been experimentally established that married adults are much happier than unmarried ones [58][59][60]. Hypothesis 2: Family is a factor that has a positive effect on positive thinking and significant correlation exists between them.

Positive feelings are linked to the past, present and future. Feelings about the past could bring back pleasant impressions, fond memories, and happy moments. It is known to all that childhood plays critical role in person's life. The traits evolved during childhood affects later life. Instilling the habits of positive thinking in ten-year-old children could reduce teenage depression in their later life [61][62][63][64]. Hence, it allows hypothesizing that Hypothesis 3a: happy childhood promotes positive thinking and significant correlation exists between them.

Redelmeier and Kahneman [65], Richard Kammann et al. [66] concluded that people with positive mindset tend to be less or not stressed by the previous painful experiences and they handle pain better. To reinforce this, one can assume that remembering pain or joy of a childhood generate positive vibes. And we put it forward as a hypothesis. Hypothesis $3 \mathrm{~b}$ : There is a positive correlation between dwelling on happy childhood memories and positive thinking.

Studies have shown that positive people tend to have well-developed social skills. They are often engaged in interaction of wider scope [67][68][69][70]. Studying the social aspect of the positivity, some scholars have managed to reveal that positivity has to be promoted given its role on building interpersonal 
skills [71][ 72]. Friendship and love are one of the fundamental human needs. Respondents described this in the sense of "belongingness". They detailed it as "the desire for meaningful life, interpersonal attachment". Satisfaction of the need "belongingness" require relationships to retain positivity and lasting effect. Studies have shown that the most life-loving people maintain wider scope social relationships with friends and relatives and they are hardly left alone [73][74]75[76][77][78]. Hypothesis 4asuggests to argue that having friend stimulates positive thinking and significant correlation exists between them.

There are studies implying the feeling of love as a skill, good character trait [50-53]. As per the study by Diner et al. [77], the happiest participants in the survey were those that had respective feelings. This was evident in all participants representing seventeen nationalities. Hypothesis $4 \mathrm{~b}$ : Living with love has positive impact on positive thinking and significant correlation exists between them.

Satisfaction with life is associated with the present time. This includes perceiving life meaningful and with joy, seeing life special. Satisfaction with life manifests itself in one's thoughts, feelings, and behavior. It has been proved that perceiving life in a positive light helps to attain longer life [23][24][25][26][27]. Satisfaction with life and seeing the beauty in life, affects interpersonal relationships and all human activities. The emotional and cognitive components act together, intertwined [56-59] in the process of perception of life. The life satisfaction has proven to have a positive effect on interpersonal relationships, mental and physical health [12][13]. Hypothesis 5: Satisfaction with life has a positive effect on positive thinking and significant correlation exists between them.

Positive psychology takes a secular position in its approach to God and perceives God as a real event, far from the sense of it being extraordinary [34][35][36][37]. Although Seligman [13] in his study did not straight confer his views towards God, but by reading between lines, it is easily apprehended that he had implied God when using "a great whole," "... a superior position," and such descriptive adjectives. The more a person feels part of a whole, the more meaningful his life would be [34][35][36]. Myers' study [80] acts identical in this regard. Research has identified belief in God as an average significant factor. The real situation in our country is different from the West and we appreciate belief in God comes across as more important factor amongst people in the country. Hypothesis 6: Significant correlation exists between belief in God and positivity.

As per some of the studies, self-confidence does not always yield positive results [81][82][83]. However, other studies have proven a strong link between self-confidence and mental health [83][84][85]. Self-confidence has been explored in the context of a self-esteem [86]. Studies show that most people experience positive self illusion [34][35][36][37]. Nevertheless, Baumeister and his friends recommend boosting self-confidence, because even then, people are insured against potential failure [86]. They come out positive from the negative situation better than those lacking positive beliefs [85][86][87][88]. Hypothesis 7: Self-confidence has a positive effect on positivity, and significant correlation exists between them.

Many studies had been conducted to look into how wealth and poverty appear to impact person's mood. Many number of comparisons had been performed by researchers. The owners of great wealth at initial analysis could come across happier than those who possess nothing. Concluding his research, Warner Wilson ranked "good income" as the number one factor making person happy [13][14][15][16][17]. However, studies proving opposite also exists. According to Seligman and Csikszentmihaly [47], the rich and the poor occur to be equally unhappy. Material wealth raises the general happiness to smallest extend for shorter period [40][41][42]. In our view, comparison of countries with different economic development indicators in order to establish the role of the monetary factor does not yield accurate results.

Thus, the wage, literacy, health and education are high and the countries experience civil freedom to larger extend. In countries where the minimum wage per citizen is guaranteed and wages are generally high, high incomes do not necessarily lead to happiness. Statistics from developed countries had proven that in the last fifty years, the average purchasing power in the United States, France and Japan has doubled, but life satisfaction has remained the same [50][51][52][53]. Life satisfaction of people in poverty in Calcutta was reported as 1.93 on a three-point rating scale. This figure is slightly different from the indicators of students from the University of Calcutta [66][67][68][69]. In developing countries, wealth is closely tied with happiness. In today's world, where money is more important than anything else, it can be argued that the total income of a student's family yields positive effect on a person's well-being. Hypothesis 8: Significant correlation exists between the total income of students' families and a positive thinking. The higher the total income of the family is the more positive attitudes could be exhibited. 
Thus:

The purpose of the study: To identify some of the factors fostering positive thinking.

Hence, the following hypotheses were put forward in the study:

Hypothesis 1a: Gender does not impact positive thinking.

Hypothesis 1b: Age does not affect positive thinking.

Hypothesis 2: Family is a factor that has a positive effect on positive thinking and significant correlation exists between them.

Hypothesis 3a: happy childhood promotes positive thinking and significant correlation exists between them.

Hypothesis $3 \mathrm{~b}$ : There is a positive correlation between dwelling on happy childhood memories and positive thinking.

Hypothesis 4asuggests to argue that having friend stimulates positive thinking and significant correlation exists between them.

Hypothesis 4b: Living with love has positive impact on positive thinking and significant correlation exists between them.

Hypothesis 5:Satisfaction with life has a positive effect on positive thinking and significant correlation exists between them.

Hypothesis 6: Significant correlation exists between belief in God and positivity.

Hypothesis 7: Self-confidence has a positive effect on positivity, and significant correlation exists between them.

Hypothesis 8: Significant correlation exists between the total income of students' families and a positive thinking. The higher the total income of the family is the more positive attitudes could be exhibited.

\section{METHOD AND STATISTICAL ANALYSIS}

Questionnaire with 12 questions was used in the study. The questions were preparedin two directions. 3 questions were asked to identify positive students, while the rest served to identify factors favorablyimpacting positivity (test hypotheses).

Statistical analysis: ROC-analysis was conducted in order to check the authenticity of the answers given by the students who were identified as positive based upon their answers to 3 questions.

Statistical analysis was performed using discriminant Chi-Square Pearson, H-Kruskal-Wallis, correlation $\beta$-Kendall's tau. The calculations were performed in the IBM Statistics SPSS-26 package program.

\section{METHOD}

\section{SAMPLE}

This survey was conducted among 332 students aged 17-25 in Baku. Students from three universities in Baku took part in the study voluntarily, and no identity data was collated from the participants. Completion of survey took about 20 minutes. The survey questionnaire and the implementation method were approved by the Academy of Public Administration under the President of the Republic of Azerbaijan, Azerbaijan University of Tourism and Management and Baku Slavic University.

Socio-demographic features of the samples are shown in Table 1. As it is apparent, $49.4 \%$ of the participants were boys (164 people) while girls accounted for 50.6\% (168 people). $19.0 \%$ of them were first-year (63 people), 19.6\% second-year (65 people), $21.7 \%$ third-year (72 people), $20.5 \%$ were fourthyear students (68 people) and $19.3 \%$ were those with master degree (64 people). (see Table 1). 
Table 1. Socio-demographic features of the samples $(N=332)$

\begin{tabular}{|c|c|c|c|}
\hline & & Count & Column N $\%$ \\
\hline \multirow[t]{2}{*}{ Gender } & Boy & 164 & $\% 49.4$ \\
\hline & Girl & 168 & $\% 50.6$ \\
\hline \multirow[t]{5}{*}{ Year } & I year & 63 & $\% 19.0$ \\
\hline & II year & 65 & $\% 19.6$ \\
\hline & III year & 72 & $\% 21.7$ \\
\hline & IV year & 68 & $\% 20.5$ \\
\hline & Master degree & 64 & $\% 19.3$ \\
\hline
\end{tabular}

\section{METHODS OF COLLECTING DATA}

Results obtained. We initially set ourselves the goal of identifying positive students to enable us to identify the factors fostering positive thinking. With this in mind, we asked them 3 questions on the research card: "How do you see yourself in four years?", "How do you see yourself in six years?" and "How do you see yourself in ten years?". Those who had positively answered 2 of the three questions were assessed as positive, those who had given 2 negative answers were identified as negative oriented students (negative data was not considered as it was not included in the goal we set in this study) (see Table 2 and 3).

Table 2. Table demonstrating selection of students

\begin{tabular}{|c|c|c|c|c|c|}
\hline & \multicolumn{4}{|c|}{ Positivity } \\
\hline & & \multicolumn{2}{|c|}{ positive } & \multicolumn{2}{|c|}{ negative } \\
\hline & & Count & Column N \% & Count & Column N \% \\
\hline \multirow[t]{2}{*}{ How do you see yourself in four years? } & positive & 297 & $\% 97.7$ & 8 & $\% 28.6$ \\
\hline & negative & 7 & $\% 2.3$ & 20 & $\% 71.4$ \\
\hline \multirow[t]{2}{*}{ How do you see yourself in six years? } & positive & 296 & $\% 97.4$ & 2 & $\% 7.1$ \\
\hline & negative & 8 & $\% 2.6$ & 26 & $\% 92.9$ \\
\hline \multirow[t]{2}{*}{ How do you see yourself in ten years? } & positive & 300 & $\% 98.7$ & 8 & $\% 28.6$ \\
\hline & negative & 4 & $\% 1.3$ & 20 & $\% 71.4$ \\
\hline
\end{tabular}

Table3. NPar Tests (Ranks)

\begin{tabular}{|l|l|r|l|}
\hline Positivity & & \multicolumn{1}{|c|}{ N } & Mean Rank \\
\hline \multirow{7}{*}{} & positive & 304 & \\
\cline { 2 - 4 } & negative & 28 & \\
\cline { 2 - 4 } & Total & 332 & \\
\hline
\end{tabular}

Thusly, 304 out of 332 students were identified as students with positive thinking. At the initial stage of the study, ROC analysis was performed to verify the relevance of the positive thinking to the questions and the genuineness of the answers (Fig. 1, Table 4).
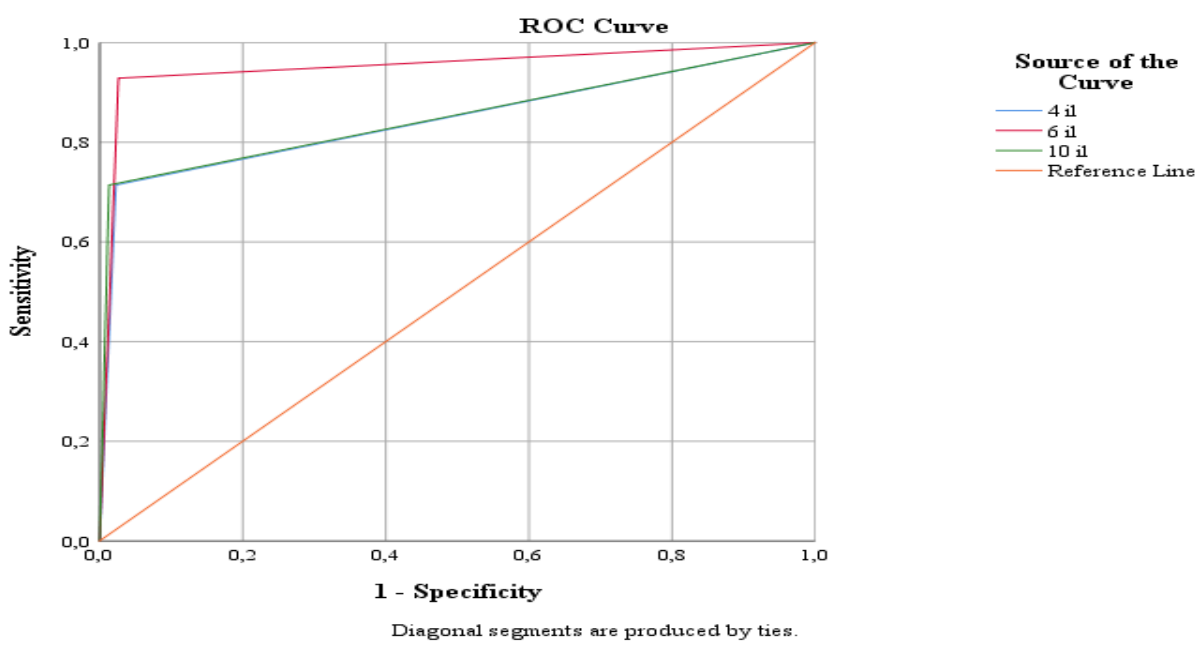

Fig.1. ROC analysis showing the sincerity of the answers 
Table 4. Area Under the Curve

\begin{tabular}{|l|l|l|l|l|l|}
\hline Test Result Variable(s) & Area & Std. Error & $\begin{array}{l}\text { Asymptotic } \\
\text { Sig. }\end{array}$ & & $\begin{array}{l}\text { Asymptotic \%95 } \\
\text { Interval }\end{array}$ \\
\cline { 4 - 6 } & & & & Confidence \\
\hline 4 years & .846 & .052 & .000 & .744 & .947 \\
\hline 6 years & .951 & .029 & .000 & .895 & 1.000 \\
\hline 10 years & .851 & .052 & .000 & .749 & .952 \\
\hline
\end{tabular}

The results of the ROC analysis allow us to accept the genuineness of the student answers to the questions and the hypothesis that the positive thinking indicator we have populated is subject to a higher sensitivity and specificity.

In the later stage, the students with positive mindset were asked to fill in the questionnaire comprising eight questions. Their responses to What makes you happy?; Did you have a happy childhood?; Do you remember the happiest moments of your childhood?; Do you have a friend?; Are you in love?; Is life beautiful?; Do you believe in God?; Are you self-confident? and Family income related survey questions were analysed.

\section{PROCESS}

Taking positive thinking as a dividing variable, all the figures obtained in the course of the study were statistically analysed in the light of modern recommendations. Statistical analysis was performed using discriminant (Chi-Square Pearson, H-Kruskal-Wallis) (Table 5), correlation ( $\beta$-Kendall's tau) (Table 6) analysis. The calculations were made via the IBM Statistics SPSS-26 package program (see Table 5, Table 6).

The positive (and negative) variables were accepted as independent variables, while all other questions were assessed to be dependent variables. Negative variables were not taken into account, as they were not included in the study.

Table 5. General table

\begin{tabular}{|c|c|c|c|c|c|c|c|}
\hline \multirow[t]{3}{*}{ Questions } & \multirow[t]{3}{*}{ Answers } & \multicolumn{4}{|c|}{ Positivity } & \multirow{3}{*}{$\begin{array}{l}\text { Pearson Chi } \\
\text { Square Tests }\end{array}$} & \multirow{3}{*}{$\begin{array}{l}\text { Kruskal- } \\
\text { Wallis H- } \\
\text { Test }\end{array}$} \\
\hline & & \multicolumn{2}{|c|}{ positive } & \multicolumn{2}{|c|}{ Negative } & & \\
\hline & & $\begin{array}{l}\text { Co } \\
\text { un } \\
t\end{array}$ & $\begin{array}{l}\text { Column } \\
\mathrm{N} \%\end{array}$ & Count & Column N \% & & \\
\hline \multirow[t]{3}{*}{ What makes you happy? } & Money & 73 & $\% 24.0$ & 14 & $\% 50.0$ & \multirow[t]{3}{*}{$\begin{array}{l}\chi 2=10.098 \\
p=.006\end{array}$} & \multirow[t]{3}{*}{$\begin{array}{l}\mathrm{H}=5.215 \\
\mathrm{p}=.022\end{array}$} \\
\hline & Family & $\begin{array}{l}20 \\
7\end{array}$ & $\% 68.1$ & 11 & $\% 39.3$ & & \\
\hline & Work & 24 & $\% 7.9$ & 3 & $\% 10.7$ & & \\
\hline \multirow[t]{2}{*}{ Did you have happy childhood? } & yes & $\begin{array}{l}26 \\
2\end{array}$ & $\% 86.2$ & 20 & $\% 71.4$ & \multirow[t]{2}{*}{$\begin{array}{l}\chi^{2}=4.364 \\
p=.037\end{array}$} & \multirow[t]{2}{*}{$\begin{array}{l}\mathrm{H}=4.351 \\
\mathrm{p}=.037\end{array}$} \\
\hline & No & 42 & $\% 13.8$ & 8 & $\% 28.6$ & & \\
\hline \multirow[t]{3}{*}{$\begin{array}{l}\text { Do you remember the happiest } \\
\text { moments of your childhood? }\end{array}$} & Yes & $\begin{array}{l}22 \\
6\end{array}$ & $\% 74.3$ & 15 & $\% 53.6$ & \multirow[t]{3}{*}{$\begin{array}{l}\chi 2=12.470 \\
p=.002\end{array}$} & \multirow[t]{3}{*}{$\begin{array}{l}\mathrm{H}=4.737 \\
\mathrm{p}=.030\end{array}$} \\
\hline & No & 2 & $\% .7$ & 2 & $\% 7.1$ & & \\
\hline & $\begin{array}{l}\text { Do not } \\
\text { remember }\end{array}$ & 76 & $\% 25.0$ & 11 & $\% 39.3$ & & \\
\hline \multirow[t]{2}{*}{ Do you have friend? } & Yes & $\begin{array}{l}26 \\
4\end{array}$ & $\% 86.8$ & 20 & $\% 71.4$ & \multirow[t]{2}{*}{$\begin{array}{l}\chi 2=4.925 \\
p=.026\end{array}$} & \multirow[t]{2}{*}{$\begin{array}{l}\mathrm{H}=4.910 \\
\mathrm{p}=.027\end{array}$} \\
\hline & No & 40 & $\% 13.2$ & 8 & $\% 28.6$ & & \\
\hline \multirow[t]{2}{*}{ Are you in love? } & Yes & $\begin{array}{l}20 \\
5\end{array}$ & $\% 67.4$ & 12 & $\% 42.9$ & \multirow[t]{2}{*}{$\begin{array}{l}\chi 2=6.840 \\
p=.009\end{array}$} & \multirow[t]{2}{*}{$\begin{array}{l}\mathrm{H}=6.820 \\
\mathrm{p}=0.009\end{array}$} \\
\hline & No & 99 & $\% 32.6$ & 16 & $\% 57.1$ & & \\
\hline $\begin{array}{l}\text { Do you think the life is } \\
\text { beautiful? }\end{array}$ & Yes & $\begin{array}{l}24 \\
8\end{array}$ & $\% 81,8$ & 13 & $\% 46.4$ & $\begin{array}{l}\chi 2=19.283 \\
\mathrm{p}<.001\end{array}$ & $\begin{array}{l}\mathrm{H}=19.225 \\
\mathrm{p}<.001\end{array}$ \\
\hline
\end{tabular}




\begin{tabular}{|c|c|c|c|c|c|c|c|c|c|}
\hline & & & no & 55 & $\% 18.2$ & 15 & $\% 53,6$ & & \\
\hline \multirow{3}{*}{\multicolumn{3}{|c|}{ Do you believe in God? }} & Yes & $\begin{array}{l}26 \\
5\end{array}$ & $\% 87.2$ & 18 & $\% 64.3$ & \multirow[t]{3}{*}{$\begin{array}{l}\chi 2=13.718 \\
p=.001\end{array}$} & \multirow[t]{3}{*}{$\begin{array}{l}H=9.692 \\
p=.002\end{array}$} \\
\hline & & & No & 19 & $\% 6.3$ & 7 & $\% 25.0$ & & \\
\hline & & & do not know & 20 & $\% 6.6$ & 3 & $\% 10.7$ & & \\
\hline \multirow{2}{*}{\multicolumn{3}{|c|}{ Are you self confident? }} & Yes & $\begin{array}{l}27 \\
0\end{array}$ & $\% 88.0$ & 20 & $\% 71.4$ & \multirow[t]{2}{*}{$\begin{array}{l}\chi 2=7.014 \\
p=.008\end{array}$} & \multirow[t]{2}{*}{$\begin{array}{l}H=6.993 \\
p=.008\end{array}$} \\
\hline & & & No & 34 & $\% 11.2$ & 8 & $\% 28.6$ & & \\
\hline \multirow{4}{*}{\multicolumn{3}{|c|}{ Your family income }} & $\begin{array}{l}\text { Less than } 500 \\
\text { AZN }\end{array}$ & 73 & $\% 24.0$ & 11 & $\% 39.3$ & \multirow[t]{4}{*}{$\begin{array}{l}\chi 2=4.249 \\
p=.373\end{array}$} & \multirow[t]{4}{*}{$\begin{array}{l}\mathrm{H}=3.739 \\
\mathrm{p}=.053\end{array}$} \\
\hline & & & $\begin{array}{l}\text { More than } 500 \\
\text { AZN }\end{array}$ & 97 & $\% 31.9$ & 9 & $\% 32.1$ & & \\
\hline & & & $\begin{array}{l}\text { Around } 1000 \\
\text { AZN }\end{array}$ & 61 & $\% 20.1$ & 4 & $\% 14.3$ & & \\
\hline & & & $\begin{array}{l}\text { More than } \\
1000 \text { AZN }\end{array}$ & 73 & $\% 24.0$ & 4 & $\% 14.3$ & & \\
\hline \multirow[t]{5}{*}{ Year } & 1 & 58 & \multicolumn{2}{|c|}{$19,1 \%$} & 5 & \multicolumn{2}{|c|}{$17,9 \%$} & & \\
\hline & 2 & 62 & \multicolumn{2}{|c|}{$20,4 \%$} & 3 & \multicolumn{2}{|c|}{$10,7 \%$} & & \\
\hline & 3 & 59 & \multicolumn{2}{|c|}{$19,4 \%$} & 13 & \multicolumn{2}{|c|}{$46,4 \%$} & & \\
\hline & 4 & 62 & \multicolumn{2}{|c|}{$20,4 \%$} & 6 & \multicolumn{2}{|c|}{$21,4 \%$} & & \\
\hline & mag. & \multirow{2}{*}{$\frac{63}{146}$} & 20, & & 1 & & & & \\
\hline Gender & boy & & 48, & & 18 & & & & \\
\hline & girl & 158 & 52, & & 10 & & & & \\
\hline Year & Chi-squ & & 13,805 & & & & & & \\
\hline & df & & 4 & & & & & & \\
\hline & Sig. & & 0,008 & & & & & & \\
\hline Gender & Chi-squ & & 2,712 & & & & & & \\
\hline & df & & 1 & & & & & & \\
\hline & Sig. & & 0,100 & & & & & & \\
\hline
\end{tabular}

Table 6. Kendal, staun-Correlations

\begin{tabular}{|c|c|c|c|}
\hline & & & Positivity \\
\hline \multirow[t]{22}{*}{ Kendall's tau_b } & \multirow[t]{2}{*}{ What makes you happy? } & Correlation Coefficient & -.122 \\
\hline & & Sig. (2-tailed) & .022 \\
\hline & \multirow{2}{*}{$\begin{array}{l}\text { Did you have a happy } \\
\text { childhood? }\end{array}$} & Correlation Coefficient & .115 \\
\hline & & Sig. (2-tailed) & .037 \\
\hline & \multirow{2}{*}{$\begin{array}{l}\text { Do you remember the happiest } \\
\text { moments in your childhood? }\end{array}$} & Correlation Coefficient & .119 \\
\hline & & Sig. (2-tailed) & .030 \\
\hline & \multirow[t]{2}{*}{ Do you have a friend? } & Correlation Coefficient & .122 \\
\hline & & Sig. (2-tailed) & .027 \\
\hline & \multirow[t]{2}{*}{ Are you in love? } & Correlation Coefficient & .144 \\
\hline & & Sig. (2-tailed) & .009 \\
\hline & \multirow{2}{*}{$\begin{array}{l}\text { Do you think the life is } \\
\text { beautiful? }\end{array}$} & Correlation Coefficient & 241 \\
\hline & & Sig. (2-tailed) & .000 \\
\hline & \multirow[t]{2}{*}{ Do you believe in God? } & Correlation Coefficient & .168 \\
\hline & & Sig. (2-tailed) & .002 \\
\hline & \multirow[t]{2}{*}{ Are you self confident? } & Correlation Coefficient & .145 \\
\hline & & Sig. (2-tailed) & .008 \\
\hline & \multirow[t]{2}{*}{ Your family income } & Correlation Coefficient & -.097 \\
\hline & & Sig. (2-tailed) & .053 \\
\hline & \multirow{2}{*}{ Year } & Correlation Coefficient & -.038 \\
\hline & & Sig. (2-tailed) & .440 \\
\hline & \multirow[t]{2}{*}{ Gender } & Correlation Coefficient & -.090 \\
\hline & & Sig. (2-tailed) & .100 \\
\hline
\end{tabular}




\section{RESULTS AND DISCUSSION}

The correlation between student positivity and gender. The positive oriented students the survey had identified comprised of $(\mathrm{N}=304), 48.0 \%$ boys (146) and $52.0 \%$ (158) girls. 18 boys, $64.3 \%$ (18 people) and $35.7 \%$ girls (10 people) were established to have negative thinking. The result of the analysis is as follows: $((\mathrm{N}=304)=\chi 2=2.712 ; \mathrm{p}=.008)$. Negative correlation between students' positive thinking and gender is insignificant $(\rho=-090 ; p=0.1)$. Thus, Hypothesis 1a is proven.

The correlation between age and positivity. The results of the analysis: $(\chi 2=13.805 ; \mathrm{p}=.008)$. While polychoric analysis suggested a correlation between age and positivity, correlation analysis did not prove its existence ( $\rho=-038 ; \mathrm{p}=.440)$. Thus, Hypothesis $1 \mathrm{~b}$ is accepted on this front.

The impact of a family on positive thinking. What makes you happy? The responses dictated $24.0 \%$ money, $68.1 \%$ family, and $7.9 \%$ work for the students who had answered in the affirmative to the questions. The result of the analysis is as follows: $(\chi 2=10.1 \mathrm{p}=0.006 ; \mathrm{H}=5.215 \mathrm{p}=.022)$. Apparently, the vast majority of students with positive mindset preferred family. This shows the family's correlation to positivity. The Kendall tau correlation was also confirmed: $\beta=-.122 \mathrm{p}=.022$. The correlation between the family and positivity hade dictated Hypothesis 2.

Did you have a happy childhood? $86 \%$ of students with positive mindset had stated their responses as "yes" and 13.80\% "no". The result of the analysis is as follows: $(\chi 2=4.364 \mathrm{p}=.037 ; \mathrm{H}=4.351, \mathrm{p}=.037)$. The correlation analysis had also proven it $(\beta=.115 ; \mathrm{p}=.037)$. It is clear from the analysis that a happy childhood causes positivity ( $\mathrm{p}<.05$ ). Hypothesis $3 \mathrm{a}$ is proven.

Do you remember the happiest moments of your childhood? $74.3 \%$ had their answers as "yes", $0.75 \%$ as "no" and $25.0 \%$ replied saying "do not remember". The result of the analysis is as follows: $(\chi 2=12.470$ $\mathrm{p}=.002 ; \mathrm{H}=4.737 \mathrm{p}=0.030)$. There is a statistically significant difference. The correlation confirmed it $(\beta=0.119, \mathrm{p}=.030$. Hypothesis $3 \mathrm{~b}$ is proven.

Do you have a friend? $86.8 \%$ answers were affirmative while $13.2 \%$ as negative. The result of the analysis is as follows: $(\chi 2=4.925 \mathrm{p}=.026 ; \mathrm{H}=4.910 \mathrm{p}=.027)$. There is a statistically significant difference between them. The correlation analysis also confirmed the outcome $(\beta=.122, \mathrm{p} .027)$. Hypothesis $4 a$ is proven.

The relationship between feeling of love and positivity. Are you in love? 67.4\% answers were "yes", while $32.6 \%$ replied negatively. The result of the analysis is as follows: $(\chi 2=6.840 \mathrm{p}=.009 ; \mathrm{H}=6.820 \mathrm{p}$ $=.009)$. There is a statistically significant difference. The correlation has proven it $(\beta=.144 \mathrm{p}=.009)$. Hypothesis $4 \mathrm{~b}$ is proven.

The relationship between students' positive attitudes and perception of life. Is life beautiful? $81.6 \%$ answered "yes" and $18.1 \%$ had pencilled their answers as "no". The results of the analysis: $(\chi 2=19.283 \mathrm{p}$ $<.001 ; \mathrm{H}=19.225 \mathrm{p}<.001)$. The correlation has also proven it $(\beta=0.241 ; \mathrm{p}<.001)$. Hypothesis 5 is proven.

The relationship between the faith in God and positivity. Do you believe in God? 87.2\% answers were "yes", while $6.3 \%$ said "no" and 6.6\% "did not know". The result of the analysis is as follows: $(\chi 2=13.718 \mathrm{p}$ $=.001 ; \mathrm{H}=9.692 \mathrm{p}=.002)$. The correlation has also proven it $(\beta=.168 ; \mathrm{p}=.002)$. Hypothesis 6 is proven.

The relationship between self-confidence and positivity. Are you confident? 88.8\% answered "yes" and $11.2 \%$ answers were "no". The result of the analysis is as follows: $(\chi 2=7.014 \mathrm{p}=.008 ; \mathrm{H}=6.993 \mathrm{p}$ $=.008)$. There is a statistically significant difference. The correlation has also proven it $(\beta=.145 ; \mathrm{p}=$ $.008)$. Hypothesis 7 is proven.

The relationship between the total family income and the positive thinking. $24.0 \%$ of students have families with less than $500 \mathrm{AZN}$ total income, while $24.9 \%$ families make more than $1000 \mathrm{AZN}$. The income of $31.9 \%$ is more than $500 \mathrm{AZN}$ and $20.1 \%$ earns about $1000 \mathrm{AZN}$. The result of the analysis is as follows: $\left(\chi^{2}=4.249 \mathrm{p}=.373 ; \mathrm{H}=3.739 \mathrm{p}=.053\right)$. Correlation $(\beta=-.097 \mathrm{p}=.053)$. In the sense of the degree of significance, it appears there is no statistically significant difference. Although negative correlation occurs between the positive thinking and the total income of the families, it sill stands to be insignificant. Hypothesis 8 is not proven.

The results of this study has dictated that the vast majority of respondents $-91.20 \%$ were the ones with positive mindset $(\mathrm{N}=332)$. Positive thinking triggers happiness [11][12][13][14]. Although research on 
the qualities of positive people had managed to identify certain respective qualities, the factors positively affecting positive thinking are still being studied.

In this study, some of the factors impacting students' positive thinking had been identified and the suggested hypotheses were largely confirmed. The results of the existing study were compared with the relevant psychological literature and the factors positively impacting and also those with no impact on positive thinking were debated.

The results of the current work aim to point readers in the right direction in shaping positive mindset.

The analysis of responses had revealed that the formation of positive mindset were favourably influenced by family, happy childhood, friendship, love, optimistic outlook, self-confidence and faith in God, while total income of family, age and gender were evaluated as non impacting components on that front. The results we obtained appear to coincide with the outcome of previous studies. These results could be discussed in the light of similar studies.

The study examined the influence of demographic factors (age and gender) on the formation of positive thinking of students. The statistical analysis of the results confirmed that the age of the students did not have any effect on shaping the positive thinking. Our conclusion is that positivity is not associated with the age and this is supported by the results of previous studies [55][56][57][58][59][60][61][62][63]. The results dictated that gender was not a factor influencing positive thinking. Number of studies occur to confirm it [44][45][46][47][48].

One of the conclusions reached through this study dictates that the family is an invaluable asset for positively thinking students and the family is associated with positive mindset. Students give higher priority to family and value family to greater extend. The effect of the family on positivity has appeared to coincide with the results of the previous studies [84][85][86].

Our study came to prove the assumption of a childhood influencing positivity. The analysis of the results had confirmed the impact of a happy childhood on the positive thinking of younger generation and the results yielded appear consistent with the outcome of previous studies.

The majority of positively tuned students $(74.3 \% \mathrm{~N}=304)$ were those who appeared to remember the positive moments of their childhood. The accuracy of the results showed that positive correlation exists between positive memories and positive thinking. The correlation between positive childhood memories and positive thinking was proven by the results of an existing research [3][11][17].

This study evidences the love as a factor influencing favourably to the positive thinking of younger generation. Diner et al. [55] showed that $10 \%$ of the happiest respondents were the ones with romantic feelings. In the current study (in our study), $67.4 \%$ of positively motivated students were the ones experiencing love. Love is a great emotion capable to change the meaning of life, elevates person, turns a person into a better version of who they are, heals people.

The current study had assumed a positive effect of friendship in fostering positive mindset and confirmed the role of friendship in positive thinking in the view of the accuracy of the results obtained. Previous studies have detailed social relationships, including friendships occurring in an association with positivity [67][68][69][70][71][72][73].

The results detected a positive correlation between the positivity and perception of life. Perceiving life through a positive lens acts as a foundation of happiness [77][78][79][80][81][82][83][84][85][86]. The results of our study are consistent with the outcome of other studies [89][90].

The study of the relationship between belief in God and positivity had revealed that $87.2 \%$ of positively motivated students appear to have faith $(\mathrm{N}=304)$ in God. The study positioned the belief in God as a factor positively influencing positive attitudes. This is supported by the results of specific studies in the literature on the correlation between belief in God and positivity.

Our results show that students' self-confidence also stands out as a factor favourably influencing positive attitudes. An analysis of the literature views positive people with high self-esteem $[23][24][25][26][27][28]$. 


\section{CONCLUSION}

Contrary to the expectations, the positive correlation between the total income of students' families and positive attitudes, we had initially presumed did not justify itself in the study. An analysis of the results viewed lack of an effective association between the family income and students' positive thinking. This conclusion is confirmed by the results of previous studies [36][37][38][39][40][41][42]. Studies have shown that one will always be dissatisfied with the income and life in general if for him money is more important than other values. This is because the subjective importance of money is stronger than the actual financial level [54][55][56][57]. Non-existence of an association between the family income and the positive thinking coincides with the results of previous studies [12][14][19].

This study identified some of the factors fostering students' positive thinking. The factors fostering youth's positive thinking could be cited and used when working with younger generation in the country. The results yielded expands the theoretical knowledge on the subject and are likely to be used in practice. The current research is thought to have made an important contribution to the literature by focusing on positivity. Future research may deliver more information through identification of other factors to shape positive mindset.

\section{REFERENCES}

[1] Aspinwall Lisa C., Richter L. and Hoffmann JR.R. (2001). Understanding how optimism works: An «Examination of optimists' adaptive moderation of belief and behavior. In E.C. Chang (Ed.)

[2] Aspinwall Lisa G., Ursula M Staudinger (2003). A psychology of human strengths: Fundamental questions and future directions for a positive psychology. Publisher. American Psychological Association

[3] Aspinwall, Lisa G., Linda Richter (1999). Optimism and Self-Mastery Predict More Rapid Disengagement from Unsolvable Tasks in the Presence of Alternatives, Motivation and Emotion, volume 23, Pages 221-245

[4] Atherton, S., Antley, A., Evans, N., Cernis, E., Lister, R., Dunn, G., Slater, M., \& Freeman, D. (2016). Self-confidence and paranoia: An experimental study using an immersive virtual reality social situation. Behavioural and Cognitive Psychotherapy, 44, 56-64. doi:10.1017/S1352465814000496

[5] Baumeister, R. F., Campbell, J. D., Krueger, J. I., \& Vohs, K. D. (2003). Does high self-esteem cause better performance, interpersonal success, happiness, or healthier lifestyles? Psychological Science in the Public Interest, 4, 1-44. doi:10.1111/1529-1006.01431

[6] Kahneman, D. and Tversky, A. (2009). Choices, values and frames. New York: Cambridje, $286 \mathrm{p}$

[7] White, D.K., Keysor, J.J., Neogi, T., Felson, D.T, LaValley, M., Gross, K.D, Fredman, L. (2012). When it hurts, a positive attitude may help: Association of positive affect with daily walking in knee osteoarthritis. Results from a multicenter longitudinal cohort study. Arthritis Care and Research. 64(9):1312-1319. [PMC free article] [PubMed] [Google Scholar].

[8] Baumeister, R.F. (1991). Meanings of Life. New York Guilford Press. 426 pp.

[9] Boniwell, I. (2012). Positive Psychology in a Nutshell, Mc. Graw Hill, Oren Un-ti Press, 218p.

[10] Fredrickson, B. (2001). The role of positive emotions in Positive Psychology: The broaden-and build theory of positive emotions. Amerikan Psychologist, 56, p218-226.

[11] Brickman, P., Coates, D., Janoff-Bulman, R. (1978). Lottery winners and accident victims: is happiness relative? J Pers Soc Psychol; 36: 917-27.

[12] Brinkman, D. J., Tichelaar, J., van Agtmael, M. A., de Vries, T. P. G. M., \& Richir, M. C. (2015). Self-reported confidence in prescribing skills correlates poorly with assessed competence in fourthyear medical students. Journal of Clinical Pharmacology, 55, 825-830. doi:10.1002/jcph.474

[13] Seligman, M. Authentic happiness. Synopsis literary Agenc, 2002, 286 p.

[14] Bryant, M. Stone, Kathleen Schmidt. (2020). Positive psychological interventions and cognition. The Journal of Positive Psychology. Pages 629-632, https://doi.org/10.1080/17439760.2020.1789714

[15] Christopher G. Ellison, Daisy Fan. (2008). Daily Spiritual Experiences and Psychological Wellbeing Among US Adults. September 2008, Social Indicators Research 88(2):247-

271.DOI: $10.1007 / \mathrm{s} 11205-007-9187-2$ 
[16] Christopher Peterson. (2006). A Primer in Positive Psychology (Oxford University Press , 386 p.

[17] Ciarrochi, J., Kashadan, T., and Harris, R. (2013). "The foundations of flourishing," in Mindfulness, Acceptance and Positive Psychology: The Seven Foundations of Wellbeing, T. Kashadan and J. Ciarrochi eds., Oakland: Context Press. pp. 1-29

[18] Clark, N. M., \& Gakuru, O. N. (2014). The effect on health and self-confidence of participation in collaborative learning activities. Health Education \& Behavior, 41, 476-484. doi:10.1177/1090198114549157

[19] Danner, D., Snowdon, D. and Friesen, W. (2001). Positive emo tions in early life and longevity: Findings from the nun study. Journal of Personality and Social Psychology, 80), 804-813.

[20] Deiner, E. and Seligman, M.E.P. (2002). Very happy people. Psychological Science, 13, 81-84. https://doi.org/10.1111\%2F1467-9280.00415

[21] Delamothe Tony.(2005). Happiness Get happy—it's good for you. Dec 24; 331(7531): 1489-1490. doi: $10.1136 / \mathrm{bmj} .331 .7531 .1489$

[22] Diener, E., and Suh, E. (1997). Measuring quality of life: Economic, social and subjective indicators. Social Indicators, 40, 189-216.

[23] Fredrickson, B. (1998). What good are positive emotions? Review of General Psychology, p. 300319. doi: 10.1037/1089-2680.2.3.300

[24] Diamond, Lisa M., Lisa G Aspinwall, (2003). Emotion regulation across the life span: An integrative perspective emphasizing self-regulation, positive affect, and dyadic processes. Journal Motivation and Emotion Volume 27, Issue 2, Pages 125-156

[25] Diener, E., and Suh, E. (1998). Age and subjective well-being: An international analysis. Annual Review of Gerontology, 17, 304-324

[26] Diener, E., Horwits, J. and Emmons R. (1995). Happiness of the very wealthy. American Psychologist, 16, 263-274. Positive Psycology: An İntroduction. (Special issue). American Psychologist, 16, 263-274.

[27] Diener, E., Suh, E., Lucas, R. and Smith, H. (1999). Subjective well-being: Three decades of progress. Psychological Bulletin, 125, 276-302. https://dornsife.usc.edu/assets/sites/780/docs/99_wb_schw_strack_reports_of_wb.pdf

[28] Dweck, C.S. (1999). Caution-Praise Can be Dangerous. Retrieved : https://positivepsychology.com/positive-parenting/

[29] Ellison, C.G., Gay, D.A., and Glass, T.A. (1989). Does religious commitment contribute to individual life satisfaction? Social Forces, 68, 100-123.

[30] Ellison, Christopher G., Amy M.Burdette, Terrence D.Hill. (2009). Blessed assurance: Religion, anxiety, and tranquility among US adults. Social Science Research, Volume 38, Issue 3, September 2009, Pages 656-667, https://doi.org/10.1016/j.ssresearch.2009.02.002

[31] Forsyth, D. R., Lawrence, N. K., Burnette, J. L. \& Baumeister, R. R. (2007). Attempting to improve the academic performance of struggling college students by bolstering their self-esteem: An intervention that backfired. Journal of Social and Clinical Psychology, 26, 447-459. doi:10.1521/jscp.2007.26.4.447

[32] Fredrickson, B. and Levenson, R. (1998). Positive emotions speed recovery from the cardiovascular sequelae of negative emotions. Cognition and Emotion, p.191-220. DOI: $10.1080 / 026999398379718$

[33] Gloppen, K. M., David-Ferdon, C. \& Bates, J. (2010). Confidence as a predictor of sexual and reproductive health outcomes for youth. Journal of Adolescent Health, 46, S42-S58. doi: 10.1016/j.jadohealth. 2009.11.216.

[34] Harker, L, and Keltner, D. (2001). Expressions of positive emo tion in women's college yearbook pictures and their relationship to personality and life outcomes across adulthood, journal of Personality and Social Psychology, 80,112-124.

[35] Hazan, C. (2002). The capacity to love and be loved. In C Peterson and M. Seligman, The VIA Classification of strengths and virtues. Washington, D.C.: American Psychological Association Press.

[36] Isen, A.M. (2000). Positive affect and decision making. In M. Lewis and J.M. Haviland-Jones (Eds.), Handbook of emotions (2d ed, pp. 417-435). New York: Guilford Press.

[37] Kamen-Siegel, L., Rodin, J., Seligman, M.E.P. and Dwyer, C. (1991). Explanatory style and cellmediated immunity. Health Psychology, 10, 229-235. 
[38] Kaori Kato, Richard Zweig, Clyde B. Schechter, Nir Barzilai and Gil Atzmon, (2017). Positive Attitude Towards Life, Emotional Expression, self-rated health, and depressive symptoms among centenarians and near-centenarians. Published online Jun 26. doi: 10.1080/13607863.2015.1056770

[39] Karney, B., and Bradbury, T. (2000). Attributions in marriage: state or trait? A growth curve analysis. Journal of Personality and Social Psychology, 78,295-309.

[40] King, L. A., Eells, J. E.a and Burton, C. M. (2012). The Good Life, Broadly and Narrowly Considered. DOI: 10.1002/9780470939338.ch3

[41] Layard, R. (2005). Happiness: lessons from a new science. London: Allen Lane. Penguin Books 2005. $310 \mathrm{pp}$.

[42] Lund, D.A., Utz, R, Caserta, M.S., De Vries, B. (2008-2009). Humor, laughter, and happiness in the daily lives of recently bereaved spouses. Omega. 58(2):87-105. [PMC free article] [PubMed] [Google Scholar]

[43] Lyubomirsy, S., and Lepper, H. S. (1999). A measure of subjec- tve happiness: Preliminary reliability and construct validation. Social Indicators Research, 46,137-155.

[44] Mroczek, D.K., and Kolarz, C.M. (1998). The effect of age on positive and negative affect: A developmental perspective on happiness. Journal of Personality and Social Psychology, 75,1333-1349

[45] Mann, M., Hosman, C. M. H., Schaalma, H. P., \& de Vries, N. K. (2004). Self-esteem in a broadspectrum approach for mental health promotion. Health Education Research, 19, 357-372. doi:10.1093/her/cyg041

[46] Masters, J., Barden, R. and Ford, M. (1979) Affective states, expressive behavior, nd learning in children. Journal of Personality and Social Psychology, 37,380-390.

[47] Seligman, M.E.P., Csikszentmihalyi, M. (2014). Flow and the foundations of positive psychology, pages 279-298, Publisher Springer, Dordrecht

[48] Maruta, T., Colligan, R., Malinchoc, M. and Of ford, K. (2000). Optimists vs. Pessimists: Survival rate among medical patients over a 30-year period. Mayo Clinic Proceedings, 75,140-143.

[49] Mobius, M. M., Niederle, M., Niehaus, P. \& Rosenblat, T. S. (2011). Managing self-confidence: Theory and experimental evidence. National Bureau of Economic Research, working paper. doi:10.3386/w17014

[50] Naheed Hasan, Thomas G. Power (2002), Optimism and pessimism in children: A study of parenting correlates, First Published March 1, 2002 Research Article, https://doi.org/10.1080/01650250114300003

[51] Nolen-Hoeksema, S., and Rusting, C L. (2000). Gender differences in well-being. In D. Kahneman, E. Diener, and N. Schwarz (Eds.), Well-being: The foundations of hedonic psychology. New York: Russell Sage Foundation.

[52] Oney, E., \& Oksuzoglu-Guven, G. (2015). Confidence: A critical review of the literature and an alternative perspective for general and specific self-confidence. Psychological Reports, 116, p.149163. doi: 10.2466/07.PR0.116k14w0.

[53] Özkan Çikrıkci, Evren Erzen and İlknur Akistanbullu Yeniçeri. (2018). Self-Esteem and Optimism as Mediators in the Relationship Between Test Anxiety and Life Satis faction Among a SchoolBased Sample of Adolescents, Published online by Cambridge University Press: Volume 29? Issue 1, June, pp. 39-53. https://www.cambridge.org/core/journals/journal-of-psychologists-andcounsellors-in-chools/CB5E5F83E9ACCD331CE24C0331A362CA.

[54] Patricia, A. Thomas, Hui Liu, and Debra Umberson. (2017). Family Relationships and Well-Being, Innov Aging. Nov; 1(3): igx025.Published online Nov 11. doi: 10.1093/geroni/igx025, PMCID: PMC5954612, PMID: 29795792

[55] Diener, Ed., Kahneman, D., Norbert Schwarz (1998). Well-being: The foundations of hedonic psychology.

[56] Patty Van Cappelen, Maria Toth-Gautheir, Vassilis Saroglou and Barabara L.,Fredrickson. (2016). Religion and Well-Being: The Mediating Role of Positive Emotions. Journal of Happiness Studies vilume 17, pages $485-505$

[57] Peter Schulman, Donald Keith, Martin E.P. Seligman. (1993). Is optimism heritable? A study of twins. Behaviour Research and Therapy. Volume 31, Issue 6, July 1993, Pages 569-574. https://doi.org/10.1016/0005-7967(93)90108-7 
[58] Redelheimer, D., and Singh, S. (2001). Social status and life expectancy in an advantaged population: A study of Academy Award-winning actors. Annals of Internal Medicine, 134, 56. https://www.academia.edu/41537209/Authentic_Happiness.

[59] Richens, M.L. and Dawson, S. (1992). A consumer values orientation for materialism and its measurement: Scale development and validation. Journal of Consumer Research, 19, 303-316.

[60] Ruch, W, Proyer, RT, Weber, M. (2010). Humor as a character strength among the elderly: Empirical findings on age-related changes and its contribution to satisfaction with life. Zeitschrift fur Gerontologie und Geriatrie. 43(1):13-18. [PubMed] [Google Scholar].

[61] Rutter, M. (1980). The long-term effects of early experience. Developmental Medicine and Child Neurology, 22,800-815.

[62] of painful medical treatments: Real-time and retrospective evaluations of two minimally invasive procedures. Pain, 116, 3-8

[63] Ryan, R. (2001) On happiness and human potential. New York: Knopf, 362 p.

[64] Segerstrom, S., Taylor, S., Kemeny, M., and Fahey, J. (1998). Optimism is associated with mood, coping, and immune change in response to stress. Journal of Personality and Social Psychology, 74 (6), 1646-1655.

[65] Redelmeier, D. A., \& Kahneman, D. (1996). Patients' memories of painful medical treatments: Realtime and retrospective evaluations of two minimally invasive procedures. pain, 66(1), 3-8.

[66] Richard Kammann, Marcelle Farry and Peter Herbison. (1984). The analysis and measurement of happiness as a sense of well-being. Social Indicators Research volume 15, pages 91-115.

[67] Seligman, M., Csikszentmihalyi, M. (2000). Positive Psychology: An introduction. American Psychologist, 55(1), p. 5-14.

[68] Seligman, M.E.P. (1994). What you can change and what you can't. New York: Knopf.

[69] Seligman, M.E.P., and Fowler, R.D. (2011). Comprehensive solider fitnes and the future of psychology. American Psychologist, 66(1), 82-86

[70] Seligman, M.E.P., Parks. A.C., Steen, T. (2004). A balanced psychology and a full life. Phil Trans R Soc Lond B; 359: 1379-81

[71] Sidney Shrauger, J., Mary Schohn. (1995). Self-Confidence in College Students: Conceptualization, Measurement, and Behavioral Implications. https://doi.org/10.1177/1073191195002003006

[72] Sirgy, M. J. (1998). Materialism and quality of life. Social Indicators Research, 43, 227-260.

[73] Spilka, B., Brawn, G.A. and Cassidy, S.A. (1992). The structure of religious mystical experience in relation to pre- and postexperience lifestyles. International Journal for the Psychology of Religion, 2,241

[74] Stankov, L. \& Lee, J. (2014). Quest for the best non-cognitive predictor of academic achievement. Educational Psychology, 34, 1-8. doi:10.1080/01443410.2013.858908.

[75] Stankov, L. (2013). Noncognitive predictors of intelligence and academic achievement: An important role of confidence. Personality and Individual Differences, 55, 727-732. doi: 10.1016/j.paid.2013.07.006

[76] Tellegen, A., Lykken, D. T., Bouchard, T.J., Wilcox, K.J., Segal, N.L. and Rich, S. (1988). Personality similarity in twins reared apart and together. Journal of Personality and Social Psychology, 54,1031-1039.

[77] Diner, Ed., Wirtz, D., Biswas-Diner R., William, T. (2009). New Measures of Well-Being. DOI: 10.1007/978-90-481-2354-4_12 /.In book: Assessing Well-Being (pp.247-266)

[78] Timothy C. Bates, (2015).The Glass is Half Full and Half Empty: A population-representative twin study testing if Optimism and Pessimism are distinct systems. Published online 2015 Feb 25. doi: 10.1080/17439760.2015.1015155 Tony Delamothe, deputy editor.

[79] United Nations General Assembly: Universal Declaration of Human Rights. New York: UN General Assembly, 1948. (2017). Available at: http://www.un.org/en/universal-declaration-humanrights/index.html/. Accessed December 23, 2017.

[80] Myers, D. (2000). The funds, friends, and faith of happy people.mAmerican Psychologist, 55, 5667. Positive Psycology: An İntroduction. (Special issue). American Psychologist, 200, 55, 5-14.

[81] Whitley, R, Henwood, B.F. (2014). Life, liberty, and the pursuit of happiness: reframing inequities experienced by people with severe mental illness. Psychiatric Rehabil J 37:68-70 
[82] Wilson, W. (1967). Correlates of avowed happiness/ Psychological Bulletin,67, p.294-306

[83] Wong, W.C., Lau, H.P, Kwok, C.F., Leung, Y.M, Chan, M.Y, Cheung, S.L. (2014). The well-being of community-dwelling near-centenarians and centenarians in Hong-Kong: A qualitative study. BMC Geriatrics. 14:63. [PMC free article] [PubMed] [Google Scholar]

[84] Wood, W., Rhodes, N. and Whelan, M. (1989). Sex differences in positive well-being: A consideration of emotional style and marital status. Psychological Bulletin, 106, 249-264.

[85] Xu, J., Roberts, R.E. (2010). The power of positive emotions. It's a matter of life or death subjective well-being and longevity over 28 years in a general populayion. Health Psychology. 29(1):9-19 [PubMed] [Google Scholar] The article was published with the support of the international scientific publishing house "Vzglyad uchenogo" https://scientist-view.ru

[86] R. Kaviani, Formation Methods and Properties of Gaseous Hydrates. Int. J. Adv. Stu. Hum. Soc. Sci., 2020, 9(4), 281-290. DOI: http://dx.doi.org/10.22034/ijashss.2020.257698.1025

[87] Y .Raziani, S. Raziani, Investigating the Predictors of Overweight and Obesity in Children. Int. J. Adv. Stu. Hum. Soc. Sci., 2020, 9(4), 262-280. DOI: http://dx.doi.org/10.22034/ijashss.2020.256464.1023

[88] Bozorgian, Investigating the Unknown Abilities of Natural Gas Hydrates. Int. J. Adv. Stu. Hum. Soc. Sci., 2020, 9(4), 241-251. DOI: http://dx.doi.org/10.22034/ijashss.2020.255633.1021

[89] Samimi, M. Samimi, Investigation of Risk Management in Food Industry. Int. J. Adv. Stu. Hum. Soc. Sci., 2020, 9(3), 195-204.DOI: http://dx.doi.org/10.22034/ijashss.2020.253984.1016

[90] S. M. Sajjadi, S. Ansari, Deschooling from Religious Education in Islamic Republic of Iran: Possibility and Necessity?. Int. J. Adv. Stu. Hum. Soc. Sci., 2019, 8(4), 369-382. DOI: http://dx.doi.org/10.33945/SAMI/IJASHSS.2019.4.6

\section{Article history:}

Received 2 July 2021

First revision 30 July

Accepted 15 September 2021 